\title{
UJARAN KEBENCIAN DALAM KOLOM KOMENTAR YOUTUBE PADA TAHUN POLITIK PEMILIHAN PRESIDEN 2019
}

\author{
Fitri Jamilah ${ }^{* 1}$, Primasari Wahyuni ${ }^{2}$ \\ ${ }^{1,2}$ Universitas PGRI Yogyakarta \\ JI. IKIP PGRI I Sonosewu No.117, Sonosewu, Ngestiharjo, Kec. Kasihan, Bantul, \\ Daerah Istimewa Yogyakarta, Indonesia \\ Email: fitrijamilah9@gmail.com ${ }^{* 1}$, primasari@upy.ac.id ${ }^{2}$
}

\begin{abstract}
Abstrak
YouTube sebagai media sosial tidak hanya sebagai sarana komunikasi dalam pergaulan, tetapi dapat juga dimanfaatkan sebagai sarana komunikasi politik. Sebagai sarana komunikasi politik maka YouTube sering dimanfaatkan untuk menyampaikan pendapat dan dukungannya kepada tokoh-tokoh politik yang diusung melalui komunikasi khusunya terlihat pada kolom komentar. Berbagai gaya komunikasi dilakukan para pengguna media sosial, baik melalui komentar, kritik, saran, dan gurauan yang di dalamnya berpeluang mengandung ujaran kebencian. Artikel ini merupakan hasil penelitian kualitatif yang fokusnya untuk menginterpretasikan data yang telah didapatkan dengan penjelasan secara mendalam terhadap suatu fenomena penggunaan ujaran kebencian pada kolom komentar channel Youtube berita politik di Indonesia. Data yang telah berhasil digali, dikumpulkan, dan dicatat dalam kegiatan penelitian. Teknik uji validitas data penelitian ini menggunakan member check dan validasi pakar media. Hasil penelitian ini menunjukkan bahwa ujaran kebencian yang terjadi pada berita politik pemilihan presiden 2019 di channel YouTube dalam bentuk kata dan frasa, serta penggunaan gaya bahasa. Gaya bahasa ujaran kebencian dalam penelitian ini didominasi gaya bahasa sarkasme yang bermakna kasar, mengandung umpatan, sindiran, ejekan, serta penggunaan sebutan atau julukan pada orang lain dengan tidak menghormati atau bahkan merendahkan atau menghina.
\end{abstract}

Kata kunci: ujaran kebencian, kolom komentar, YouTube, tahun politik, pemilihan presiden

\section{HATE SPEECH IN THE YOUTUBE COMMENT COLUMN IN THE 2019 PRESIDENTIAL ELECTION POLITICAL YEAR}

\begin{abstract}
YouTube as social media is not only a means of communication in social interactions, but can also be used as a means of political communication. As a means of political communication, YouTube is often used to convey opinions and support for political figures who are promoted through communication, especially seen in the comments column. Various communication styles are carried out by social media users, either through comments, criticisms, suggestions, and jokes, which have the opportunity to contain hate speech. This article is the result of qualitative research that focuses on interpreting the data that has been obtained with an indepth explanation of the phenomenon of using hate speech in the comments column of the Youtube Channel for political news in Indonesia. Data that has been successfully extracted, collected, and recorded in research activities. The technique of testing the validity of the research data used member check and validation of media experts. The results of this study
\end{abstract}


indicate that the hate speech that occurred in the 2019 presidential election political news on the YouTube channel is in the form of words and phrases, as well as the use of language styles. The language style of hate speech in this study is dominated by sarcasm, which means rude, contains cursing, insinuation, ridicule, and the use of names or nicknames for others with disrespect or even humiliation or insult.

Keywords: hate speech, comment column, YouTube, political year, presidential election

\section{A. Pendahuluan}

Era globalisasi dan mordenisasi ditandai oleh kemajuan teknologi yang semakin pesat di seluruh dunia. Hal ini, menjadikan setiap negara atau individu di dunia dapat berhubungan dan berkomunikasi secara bebas tanpa batas. Masyarakat Indonesia pada umumnya menyambut baik hadirnya kemajuan teknologi, dikarenakan dapat mempermudah akses informasi, komunikasi, industri, pendidikan, bahkan dunia politik (Masykuri, 2010). Hal ini dapat diamati semakin banyaknya masyarakat yang senang dan membutuhkan peralatan teknologi dalam setiap aktivitas kehidupannya.

Kemudahan fasilitas yang diberikan oleh teknologi ternyata tidak selamanya memberikan pengaruh positif, tetapi juga dapat memberikan dampak atau pengaruh negatif jika tidak bijak dalam penggunaanya. Seperti saat ini, Indonesia masuk tahun politik yaitu mempersiapkan pemilihan presiden (pilpres), setelah sebelumnya juga diadakan pemilihan gubernur (pilgub) DKI yang membawa perubahan besar dan fenomenal dalam menyampaikan aspirasi. Masyarakat Indonesia dapat bebas berpendapat untuk memberikan dukungan pada calon terpilih, baik pada pemilihan pemimpin daerah maupun pusat yaitu pemilihan presiden. Pendapat para pendukung kepada setiap capres tidak hanya disampaikan secara langsung, tetapi dengan kemajuan teknologi aspirasi para pendukung dapat disampaikan melaui unggahan seperti di sosial media. Unggahan-ungaaha tersebut dapat dikemukakan secara bebas. Hal ini dapat berpeluang memberikan dampak yang kurang baik khusunya munculnya unggahan-ungahan dengan ujaran dengan diksi yang melampaui batas. Dasar kefanatikan yang berlebihan dengan tokoh politik yang telah diusung 
mengakibatkan munculnya ujaran-ujaran kebencian atau hate speech (Anggraeni \& Adrinoviarini, 2020). Data tahun 2017 menunjukkan bahwa kejahatan hate speech ditemukan sebanyak 3.325 kasus. Angka tersebut naik 44,99\% dari tahun sebelumnya, yang berjumlah 1.829 kasus (Medistiara, 2017).

Pengguna media sosial saat ini tidak hanya mengkonsumsi informasi, tetapi memungkinkan memproduksi informasi sekaligus menyebarkan informasi. Hal ini mengakibatkan perubahan karakteristik atau pola interaksi antarindividu. Pola baru dalam memanfaatkan media sosial inilah memungkinkan siapa saja aktif dan masuk kemudian dapat terlibat menjadi konsumen dan produsen informasi. Menurut Weeks \& Holbert (2013) menyatakan bahwa setiap pengguna media sosial dapat berperan sebagai distributor pesan. Media sosial berpeluang bagi penggunanya untuk berbagi informasi kepada masyarakat sesuai dengan yang dikehendakinya. Hal ini menjadi karakteristik baru bagi penggunaan media sosial, karena setiap pengguna berhak memilih, menentukan, dan menuliskan pesan, informasi atau opini yang diinginkan.

Sistem demokrasi Indonesia yang memberikan kesempatan dan hak masyarakatnya untuk berpendapat menjadi salah satu situasi untuk mengamini masyarakat dalam menyampaikan sebuah pesan, informasi, dan opini. UndangUndang Dasar 1945 pasal 28 ayat 3 menyatakan, "Setiap orang berhak kebebasan berserikat, berkumpul, dan mengeluarkan pendapat. Kemerdekaan mengemukakan pendapat merupakan bagian dari hak asasi manusia". Artinya Indonesia dapat menjamin setiap warga negaranya mengeluarkan pendapatnya terhadap suatu hal. Akan tetapi, pendapat yang disampaikan diharapkan tidak mengganggu dan mengancam persatuan bangsa terutama tidak bertujuan untuk memprovokasi.

Kemajuan teknologi khususnya media sosial disamping sebagai media komunikasi dan informasi, kini juga dapat mengakomodasi sifat agresif, progresif, serta menampilkan self performance. Goffman dalam Norhabiba \& Putri (2018) mengasumsikan bahwa ketika orang-orang berinteraksi, mereka ingin 
menampilkan gambaran dirinya dan berharap dapat diterima oleh orang lain. Di samping itu, seseorang untuk menampilkan dirinya dilengkapi dengan menggunakan atribut yang dimilikinya, misalnya aktivitas, prestasi, busana yang dipakai, rumah yang dihuni, cara berbicara, cara berjalan, pekerjaan, dan lain lain. Media sosial yang mampu mengakomodasi atribut-atribut tersebut akan memiliki daya tarik bagi para penggunanya. Sedangkan media sosial yang kurang memberikan fasilitas untuk mengenal karakter konsumennya akan ditinggalkan. Proses pengenalan karakter yang ditampilkan di media sosial saat ini kemudian dapat melahirkan budaya baru yaitu budaya narsis. Budaya narcicism meningkat seiring dengan maraknya para penggunaan sosial media. Penelitian yang dilakukan oleh Ryo Okada mahasiswa Universitas Chukyo menyimpulkan orang yang memiliki tingkat narsisme tinggi cenderung memiliki perilaku agresif yang ditunjukkan secara verbal, namun terkadang juga ditunjukkan secara langsung (Wibowo \& Silaen, 2018).

Media sosial yang berpeluang khususnya menghadirkan informasi-informasi negatif perlu juga disadari masyarakat kita. Misalnya informasi yang sifatnya hoax (berita bohong). Informasi hoax sangat mengkhawatirkan dan dapat merugikan berbagai pihak apabila diterima dan ditanggapi oleh masyarakat sebagai berita yang benar. Di samping itu, edukasi tentang penggunaan teknologi secara benar yang belum sepenuhnya dipahami masyarakat, berpeluang pada perilaku masyarakat untuk ikut menanggapi bahkan menyebarluaskannya. Fenomena yang terjadi saat ini adalah diviralkannya/disebarkannya berita-berita yang bersifat hoax yang di dalamnya ada unsur fitnah, hasutan, ujaran kebencian (hate speech) dan sebagainya. Hal ini dapat terlihat jelas sejak pilgub 2017 dan mulai terlihat lagi tahun 2018 menjelang pilpres 2019. Menurut hasil Survey Mastel dalam Juditha (2018) mengungkapkan bahwa dari 1.146 responden, 44,3\% di antaranya menerima berita hoax setiap hari dan 17,2\% menerima lebih dari satu kali dalam sehari. Bahkan media arus utama yang diandalkan sebagai media yang dapat dipercaya terkadang ikut terkontaminasi penyebaran hoax. Media arus utama juga 
menjadi saluran penyebaran informasi/berita hoax, masing-masing sebesar $1,20 \%$ (radio), 5\% (media cetak) dan 8,70\% (televisi).

Media sosial dan situs berita online dalam aktivitas penggunaannya mengalami banyak perkembangan dari tahun ke tahun. Setiap orang difasilitasi dengan mudah untuk mengungkapkan dan mengekspresikan apa saja melalui akun media sosial mereka. Mereka juga dapat membagikan atau dan menyebarluaskan berita-berita yang diinginkan secara mudah. Berita yang dibagikan juga dapat dikomentari oleh para pengguna media sosial lainnya atau sering disebut dengan netizen. Selain itu, tidak hanya situs jejaring sosial media berupa Instagram, Facebook, Path, YouTube, dan berita online lainnya juga menyediakan kolom komentar. Pembaca dapat memberikan komentar secara bebas mengenai berita yang telah dibagikan, baik komentar postif, negatif, dan komentar netral. Namun, dengan mudahnya penggunaan sosial media dan mudahnya memberikan komentar, ternyata membawa dampak tidak baik, yaitu bertumbuh suburnya praktik ujaran kebencian atau sering disebut dengan hate speech. Hate Speech (ucapan penghinaan atau kebencian) adalah tindakan komunikasi yang dilakukan oleh suatu individu atau kelompok dalam bentuk provokasi, hasutan, ataupun hinaan kepada individu atau kelompok yang lain dalam hal berbagai aspek seperti ras, warna kulit, etnis, gender, cacat, orientasi seksual, kewarganegaraan, agama, dan lain-lain (Mawarti, 2018).

Ujaran-ujaran yang muncul tersebut akan mempengaruhi perilaku manusia, atau kata bisa mempengaruhi manusia, lebih-lebih opini manusia. Opini adalah pendapat, ide atau pikiran untuk menjelaskan kecenderungan atau preferensi tertentu terhadap perspektif dan ideologi, tetapi bersifat tidak objektif karena belum mendapatkan pemastian atau pengujian, dapat pula merupakan sebuah pernyataan tentang sesuatu yang berlaku pada masa depan dan kebenaran atau kesalahannya serta tidak dapat langsung ditentukan misalnya menurut pembuktian melalui induksi (Asih \& Rosit, 2018). Makna lain adalah bahwa opini merupakan kata yang berarti tanggapan atau jawaban terhadap sesuatu 
persoalan yang dinyatakan berdasarkan kata-kata, bisa juga berupa perilaku, sikap, tindakan, pandangan, dan tanggapan (Malau, 2013). Sedangkan menurut Takariani (2015), opini adalah ekspresi sikap dengan melalui jawaban positif untuk informan yang mendukung, jawaban netral dan negatif untuk jawaban yang tidak mendukung, artinya apabila sesorang beropini positif tandanya orang tersebut mendukung, dan apabila seseorang beropini negatif artinya orang tersebut menolak.

Saat ini, media soaial tidak hanya sebagai sarana komunikasi dalam pergaulan, tetapi lebih daripada itu yaitu dapat dimanfaat sebagai sarana komunikasi politik. Sebagai sarana komunikasi politik maka sering dimanfaatkan untuk menyampaikan pendapat dan dukungannya terhadap salah satu tokoh dalam partai politik. Sebagaimana dalam kampanye tidak resmi, yaitu kampanye yang dilakukan oleh masing-masing pendukung kandidat melalui komunikasi dalam media sosial. Berbagai gaya komunikasi dilakukan para pengguna media sosial, baik melalui komentar, kritik, saran, dan gurauan yang di dalamnya berpeluang mengandung hate speech/ujaran kebencian. Ujaran kebencian tersebut tampak pada diksi yang digunakan dan gaya bahasa yang digunakan

Dalam bahasa dikenal adanya gaya bahasa atau majas. Majas merupakan sarana untuk mengekspresikan pikiran dan perasaan dengan bahasa yang indah dan personal. Menurut Al-Ma'ruf \& Imron (2014) dan Noermanzah (2012), gaya bahasa adalah style yang merupakan cara pemakaian bahasa dalam konteks tertentu, oleh penulis atau pengarang tertentu. Gaya bahasa juga memungkinkan kita dapat menilai pribadi, watak, dan kemampuan seseorang yang mempergunakan bahasa itu; semakin baik gaya bahasanya, semakin baik pula penilaian orang terhadapnya; semakin buruk gaya bahasa seseorang, semakin buruk pula penilaian diberikan padanya. Gaya bahasa merupakan cara mengungkapkan pikiran melalui gaya bahasa secara khas yang memperlihatkan jiwa dan kepribadian penulis (Nurel, 2018). 
Kata-kata kasar yang terdapat pada komentar netizen/warganet tersebut, jika dikaitkan dengan majas (gaya bahasa), disinyalir termasuk dalam majas ironi, sinisme, dan sarkasme. Majas ironi dipergunakan untuk mengingkari maksud yang sebenarnya, majas sinisme merupakan kesangsian yang mengandung ejekan, dan majas sarkasme mengandung celaan yang menyakitkan hati (Keraf, 2004). Gaya bahasa sarkasme merupakan suatu acuan yang lebih kasar yang mengandung olok-olok atau sindiran pedas dan menyakiti hati. Kata sarkasme diturunkan dari kata Yunani sarkasmos, yang lebih jauh diturunkan dari kata kerja sakasein yang berarti "merobek-robek daging seperti anjing", "menggigit bibir karena marah", atau "berbicara dengan kepahitan", misal: "Mulut kau harimau kau." (Keraf, 2004). Selain mengandung arti penyindiran, sarkasme juga merupakan ejekan atau penghinaan terhadap seseorang. Dari beberapa makna kata sarkasme tersebut, dapat disampaikan bahwa sarkasme yaitu kata-kata kasar yang sengaja digunakan seseorang untuk menyakiti hati atau perasaan orang lain yang menjadi target tuturannya.

Penggunaan sarkasme mengandung makna bahwa seorang penutur dengan sengaja melakukan usaha untuk mengganti kata-kata yang bermakna biasa dengan kata-kata lain yang mengalami penyimpangan makna yang bermakna kasar (Inderasari dkk., 2019). Sarkasme ini biasanya dilakukan orang dalam situasi yang tidak ramah atau untuk menunjukkan sikap negatif, misalnya jengkel, sebal, muak, marah, jijik, dan sebagainya.

Gaya bahasa sarkasme yang mengandung ujaran kebencian dari hasil obervasi awal di media sosial khususnya pada kolom komentar YouTube juga terjadi terutama pada tahun politik pemilihan presiden 2019. Untuk itu, penelitian ini mencoba menjawab Bagaimanakah ujaran kebencian dalam kolom komentar YouTube pada tahun politik pemilihan presiden 2019? Tujuan penelitian ini untuk mendeskripsikan apa saja bentuk bahasa yang digunakan dalam ujaran kebencian dalam kolom komentar YouTube pada tahun politik pemilihan presiden 2019. Harapannya dari hasil penelitian ini bisa bermanfaat dalam perkembangan 
penggunaan bahasa Indonesia di media sosial dan menjadi bahan masukan bagi pendidik dalam memberikan arahan kepada siswa dalam menggunakan bahasa Indonesia yang baik dan santun di media sosial.

\section{B. Metode Penelitian}

Jenis penelitian ini yakni penelitian kualitatif, penelitian kualitatif merupakan prosedur penelitian yang menghasilkan data deskripstif berupa kata-kata tertulis atau lisan dari orang-orang dan perilaku yang dapat diamati. Bentuk penelitian berupa deskriptif karena tujuan ini mendeskripsikan berusaha untuk mengkaji makna yang terkandung dalam sebuah ujaran, yakni ujaran kebencian/hate speech khususnya di channel YouTube. Adapun yang dikaji adalah makna yang terkandung dalam hate speech/ujaran kebencian yang disampaikan kepada para tokoh-tokoh calon presiden 2019 dengan mengkaji diksi yang digunakan dalam ujaran yang digunakan khususnya pada kolom komentar sepuluh channel YouTube pada tahun politik pemilihan presiden 2019.

Sepuluh channel Youtube tersebut yaitu: "Channel YouTube: tvOneNews Debat Seru: Selisih Suara Jokowi-Ma'ruf Vs Prabowo-Sandi Beda Tipis; Channel YouTube: CNN Indonesia (Hashim \& Narasi Politik Prabowo); Channel YouTube: Mata Najwa (satu atau dua: siapa paling merakyat, Jokowi atau Prabowo?) Part1; Channel YouTube: "Talkshow TvOne (Adu Kesilaman, Tiket Menuju Istana? Apa Kabar Indonesia Malam; Chanel Youtube: TVNusa (Awal tahun Presiden Jokowi Jogging dan Sapa Warga di Kebun Raya Bogor); Channel YouTube: Inspirasi News Asumsi Jokowi Kliru Ambil MA Cawapres Kata Pimred Tempo; Prabowo Sandiaga Isu Ekonomi; Debat, Chanel Youtube: tvOneNews Cawapres Sandiaga Uno Berkunjung ke Desa Kelahiran Presdien Jokowi; Channel YouTube: Kampanye ditolak, Begini klarifikasi cawapres Sandiaga Uno; dan Channel YouTube: Aktivis Kepo Prabowo Salah Sebut letak Negara Saat Pidato, Timsesnya Tepok Jidat. 
Data yang telah berhasil digali, dikumpulkan dan dicatat dalam kegiatan penelitian. Teknik uji validitas data penelitian ini menggunakan member check dan uji validasi pakar media sehingga diharapkan hasil analisis data benar-benar dapat diterima secara ilmiah. Analisis data yang digunakan pada penelitian ini menggunakan metode padan dan metode agih. Menurut Sudaryanto (1993), metode padan posisi alat penentunya di luar, terlepas, dan tidak menjadi bagian dari bahasa yang bersangkutan. Kemudian, metode agih digunakan untuk mendeskripsikan menentukan hierarki gramatikal yang terdapat pada kalimat yang mengandung ujaran kebencian. Adapun metode agih tersebut termasuk metode analisis bahasa yang alat penentunya adalah bahasa yang bersangkutan yang digunakan pada masyarakat yang memberikan komentar pada kolom YouTube.

\section{Hasil Penelitian dan Pembahasan}

\section{Hasil Penelitian}

Penelitian ini meneliti sepuluh channel Youtube yang di dalamnya ditemukan komentar mengandung ujaran kebencian (hate speech). Channel-channel YouTube tersebut yaitu: "Channel YouTube: tvOneNews Debat Seru: Selisih Suara Jokowi-Ma'ruf Vs Prabowo-Sandi Beda Tipis; Channel YouTube: CNN Indonesia (Hashim \& Narasi Politik Prabowo); Channel YouTube: Mata Najwa (satu atau dua: siapa paling merakyat, Jokowi atau Prabowo?) Part1; Channel YouTube: "Talkshow TvOne (Adu Kesilaman, Tiket Menuju Istana? Apa Kabar Indonesia Malam; Chanel Youtube: TVNusa (Awal tahun Presiden Jokowi Jogging dan Sapa Warga di Kebun Raya Bogor); Channel YouTube: Inspirasi News Asumsi Jokowi Kliru Ambil MA Cawapres Kata Pimred Tempo; Prabowo Sandiaga Isu Ekonomi; Debat, Chanel Youtube: tvOneNews Cawapres Sandiaga Uno Berkunjung ke Desa Kelahiran Presdien Jokowi; Channel YouTube: Kampanye ditolak, Begini klarifikasi cawapres Sandiaga Uno; dan Channel YouTube: Aktivis Kepo Prabowo Salah Sebut letak Negara Saat Pidato, Timsesnya Tepok Jidat. 
Pada sepuluh Channel YouTube tersebut ditemukan 100 data ujaran yang mengandung hate speech/ujaran kebencian. Gaya bahasa yang digunakan dalam ujaran pada kolom komentar channel YouTube didominasi gaya bahasa sarkasme. Gaya bahasa sarkasme tersebut unsurnya berbentuk kata dan frasa. Bentuk ujaran kata dan frasa ujaran kebencian yang mengandung gaya bahasa sarkasme dapat dilihat pada tabel berikut.

Tabel 1. Klasifikasi Gaya Bahasa Sarkasme Berdasarkan

Unsur Bentuk Frasa dan Kata

\begin{tabular}{lll}
\hline \multicolumn{1}{c}{ Sarkasme } & \multicolumn{1}{c}{ Lugas } & Bentuk \\
\hline 1. Kubu kampret & Pendukung Prabowo & Frasa \\
\hline 2. Kubu wowo Iblis yg sesat & Pendukung yang memilih Prabowo & Frasa \\
\hline 3. Bacot lu & Kata-katamu & Frasa \\
\hline 4. Cebong & pendukung Jokowi & Kata \\
\hline 5. Banyak ngomong & banyak bicara & Frasa \\
\hline 6. Prabowo-Sandi tenggelamkan & Prabowo-Sandi jangan didukung & Frasa \\
\hline 7. Prabowo kudanil & Parabowo & Frasa \\
\hline 8. Kubu prabowo gatel-gatel & Pendukung Prabowo kahawatir & Frasa \\
\hline 9. Jokowi tidak waras & Jokowi tidak sadar & Frasa \\
\hline 10. Kakek tua & Ma'ruf Amin & Frasa \\
\hline 11.Preman nasi bungkus sontoloyo & Pendukung Jokowi & Frasa \\
\hline 12.Genderuwo & Pendukung prabowo & Kata \\
\hline 13. Selalu hoak dan munafik & Berbohong & Frasa \\
\hline 14. Lambene wowo ko di rungok no & Pembicaraan Prabowo mohon di & Frasa \\
\hline 15. Goblok tenan & dengarkan & \\
\hline
\end{tabular}

Adapun ujaran dalam kolom komentar yang mengandung gaya bahasa yang telah ditemukan dalam penelitian ini keseluruhan berjumlah 100 ujaran yang tergolong ujaran kebencian. Adapun sebagai contoh hanya akan ditampilkan 12 contoh ujaran yang mengandung gaya bahasa dan tergolong dalam tuturan ujaran kebencian sebagai berikut.

Tabel 2. Klasifikasi Gaya Bahasa pada Komentar Channel YouTube Berita Politik

\begin{tabular}{cll}
\hline No. & \multicolumn{1}{c}{ Kalimat } & Gaya Bahasa \\
\hline 1. & @Sarah.azhelianasution & Sinisme \\
& Makhluk yang bermimpi memimpin tanah air & \\
\hline 2. & @Yuanita Nita & Sarkasme \\
& Hadih2 kubu kampret ko pada sesat semua, galdo cermin keburukan & \\
& kubu wowo iblis xg sesat, tetap JOKOWI 2P itu xg harus, median gak & \\
& ngaruh tetap Jokowi Yesss & \\
\hline 3. & @video lucu & Sinisme \\
& Rata-rata yang pilih Prabowo itu bocah di bawah umur yang ga ikut & \\
\hline
\end{tabular}

Silampari Bisa: Jurnal Penelitian Pendidikan Bahasa Indonesia, Daerah, dan Asing Vol. 3, No. 2, 2020 
pemilu yaitu bocah-bocah FPI.

\begin{tabular}{|c|c|c|}
\hline & pemilu yaitu bocah-bocah FPI. & \\
\hline 4. & $\begin{array}{l}\text { @Lestri Abu } \\
\text { Ntr klu dh deket pilpres jokowi nyungsep. Prabowo nguber Jokowi. }\end{array}$ & Sarkasme \\
\hline 5. & $\begin{array}{l}\text { @Sultan Handaq } \\
\text { Haha.. survey abal-abal. Suara wowo bisa naik dari mana wong } \\
\text { beberapa bulan terakhir bikin kontroversi terus. Ingat, wowo pernah } \\
\text { dipermalukan lembaga survey ini. Wowo sampai sujud syukur karena } \\
\text { mengira menang, padahal kan. Haha tapi kubu kampret emang gak } \\
\text { punya malu, jadi bisa ngomong apa. }\end{array}$ & Sarkasme \\
\hline 6. & $\begin{array}{l}\text { @Ayah Ato } \\
\text { Surve bayaran, orang bodoh pasti percaya kalau jokowi unggul tetapi } \\
\text { bagi orang cerrdas tdk percaya hasil surve yang memenangkan jokowi. }\end{array}$ & Ironi \\
\hline 7. & $\begin{array}{l}\text { @Sury raga } \\
212 \text { mana bacot luu? Hahaha aseng cina kafir makan tuh isu yang lu } \\
\text { lempar di mulai era Ahok balik ke capres lo sekarang. }\end{array}$ & Sarkasme \\
\hline 8. & $\begin{array}{l}\text { @kepo lo } \\
\text { Yang dukung wowo isinya orang munafik semua. Teriak cina teriak kafir } \\
\text { padahal capresnya aja turunannya cina. Jokowi tetap yang terbaik. }\end{array}$ & Sinisme \\
\hline 9. & $\begin{array}{l}\text { @Danny Ruzain } \\
\text { Awas banyak akun cebong. Dungu di sini }\end{array}$ & Sarkasme \\
\hline 10. & $\begin{array}{l}\text { @Mas Mosa } \\
\text { Aku yakin kalo Prabowo yang jadi presiden, indonesia malah gak } \\
\text { karuan, pasti korupsi besar2an akan terjadi seperti di era Suharto. } \\
\text { Pembangunan dikosongkan, kelola kekayaan bumi di atur secara akal } \\
\text { bulusnya. }\end{array}$ & Sinisme \\
\hline 11. & $\begin{array}{l}\text { @Yuanita Nita } \\
\text { Hadih2 kubu kampret ko pada sesat semua, galdo cermin keburukan } \\
\text { kubu wowo iblis xg sesat, tetap JOKOWI 2P itu xg harus, median gak } \\
\text { ngaruh tetap Jokowi }\end{array}$ & Sarkasme \\
\hline 12. & $\begin{array}{l}\text { @Cebong Tololsontoloyo } \\
\text { Alah pabeulitt jeung survey2...Geus loba indikasi si joko bakal keok, } \\
\text { ningali kaayaan Nagara model kiemah. }\end{array}$ & Ironi \\
\hline
\end{tabular}

Penjelasan contoh ujaran dalam kolom komentar, ujaran kebencian dapat dilihat pada contoh berikut.

(1) Hadih2 kubu kampret ko pada sesat semua, galdo cermin keburukan kubu wowo iblis xg sesat, tetap JOKOWI 2P itu xg harus, median gak ngaruh tetap Jokowi Yesss. @Yuanita Nita

Pada komentar (1) tersebut kata kampret menggantikan kata lain untuk sebutan para pendukung capres 'Prabowo'. Disamping itu ujaran tersebut juga menyatakan bahwa para pendukung Prabowo adalah pendukung yang keliru yang kemudian diujarkan dengan gaya bahasa sarkasme yaitu 'wowo iblis yg sesat'. Contoh lain misalnya sebagai berikut.

Silampari Bisa: Jurnal Penelitian Pendidikan Bahasa Indonesia, Daerah, dan Asing Vol. 3, No. 2, 2020 
(2) Hahahaha Mulut jangan asal bacot jendral, kalau tidak mengerti jangan diungkapkannya.

Pada komentar (2) tersebut mengatakan kata 'bacot' yang bermaksud 'berkata-kata' yang ditujukan kepada calon presiden Prabowo. Contoh berikut juga menggambarkan ujaran kebencian kepada kubu Jokowi. Komentar tersebut adalah sebagai berikut.

(3) Drpda pilih tua bangka anggota bpip maruf amin yg gak pnya massa. Lbh baik pilih nabi palsu Said Aqil Siraidj dgn agama haram islam nusantara. Atau Mahfud MD anggota bpip yang dibayar ratusan juta yang mulut busuknya bisa di beli leecehkan PHP bikin jas cawapres oleh tim Jokowi.

Komentar tersebut mengandung ujaran kebencian dengan gaya bahasa sarkasme yaitu frasa tua bangka, mulut busuknya.

\section{Pembahasan}

Bahasa yang digunakan oleh penulis komentar dalam media sosial channel YouTube cukup bervariasi, meliputi bahasa Indonesia yang tidak baku (ragam santai), bahasa Indonesia yang bercampur dengan bahasa daerah dan bahasa asing serta bahasa Indonesia yang banyak mengandung istilah dan ungkapan sarkastik. Ditinjau dari makna kalimatnya, diketahui pula bahwa banyak tulisan dalam channel YouTube yang mengalami penyimpangan makna secara pragmatis. Kajian ini memiliki makna dalam ujaran kebencian seperti halnya meminta 2019 ganti presiden, meminta 2019 tetap presiden Jokowi, hingga meminta janji-janji yang pernah dilontarkan presiden Jokowi kepada masyarakat.

Ujaran kebencian yang dilakukan oleh masyarat menurut Pamuji (2020) sebagai ekspresi nitizen dalam ruang jurnalisme sebagai saluran pengetahuan salah satunya dalam bentuk kebencian sebagai bentuk ekspresi atas kekecewaan terhadap sesuatu yang terjadi di masyarakat secara bebas sesuai latar belakang tertentu yang mendasarinya. Ujaran kebencian terutama dalam bentuk sarkasme ini tidak dibenarkan oleh agama dan Undang-undang Nomor 11 Tahun 2008 tentang Informasi dan Transaksi Elektronik (UU ITE) yang mana kita dibebaskan 
berpendapat, tetapi tidak boleh mengandung unsur penghinaan dan pencemaran nama baik (Hasibuan, 2019).

Sarkasme yang paling sering muncul dan digunakan para penulis pesan dalam kolom komentar media sosial channel YouTube adalah penggunaan katakata yang termasuk dalam kelompok kata bermakna kasar, mengandung umpatan, sindiran, ejekan, serta penggunaan sebutan atau julukan pada orang lain dengan tidak menghormati atau bahkan merendahkan atau menghina. Dari data yang dikumpulkan, tampak bahwa pengguna media sosial banyak yang memilih untuk mencampurkan bahasa Indonesia dengan bahasa daerahnya dalam mengekspresikan pikiran dan perasaannya. Peristiwa gejala bahasa tersebut sering disebut dengan interferensi, alih kode, dan campur kode (Riansi, 2017).

Ujaran-ujaran kebencian yang banyak dituliskan dalam kolom komentar channel YouTube berpeluang memiliki dampak yang tidak baik terhadap pola berkomunikasi masyarakat kita sebagai masyarakat yang dikenal dengan multibudaya. Fenomena hate speech atau ujaran kebencian tidak sesuai dengan fungsi bahasa yang seharusnya. Fungsi bahasa sejatinya adalah sebagai alat komunikasi dan interaksi antarbangsa, dan sebagai sarana pengungkap perasaan dan pikiran manusia serta sebagai alat untuk saling memahami, mengenali, menerima persamaan dan perbedaan antarbangsa (Noermanzah, 2019). Terlebih sebagai pengajar bahasa Indonesia, bahasa menjadi alat utama dalam memberikan pengalaman belajar kepada peserta didik sehingga membentuk pribadi yang santun. Tugas pengajar di era 5.0 juga harus memberikan keterampilan dalam mengolah bahasa dengan baik dan menghindari ujaran kebencian sehingga terbentuk kemampuan critical thinking, communication, collaboration, creativity, dan innovation (Kusmiarti dkk., 2020).

Dengan mengacu pada fenomena ujaran kebencian dalam kolom komentar channel YouTube tersebut menjadikan fungsi bahasa tersebut penting untuk dikembangkan lagi. Jika hal itu tidak diperhatikan, maka sangat mungkin sisi 
negatif dari fungsi bahasa itu akan muncul fungsi bahasa bukan menjadi sarana ekspresi secara positif melainkan juga sebagai sarana pengungkap perasaan dan pikiran manusia secara bebas dan berpeluang untuk memicu konflik, kesalahpahaman, dan pertikaian di dalam masyarakat, sebagaimana yang terjadi dalam media sosial dewasa ini.

\section{Simpulan}

Penyimpangan penggunaan bahasa secara pragmatis dalam bentuk ujaran kebencian terjadi pada kolom komentar YouTube pada tahun politik pemilihan presiden 2019. Dalam konteks penelitian ini, penyimpangan ujaran kebencian yang ditemukan adalah adanya unsur gaya bahasa sarkasme dalam bentuk kata dan frasa yang sengaja digunakan untuk kebutuhan mengekspresikan kebencian, rasa tidak senang, ketidakcocokan, menghina, mempermalukan, merendahkan, dan memberikan serangan secara verbal terhadap orang yang tidak disenangi, baik secara langsung maupun tidak langsung, ataupun secara eksplisit maupun implisit. Ujaran-ujaran kebencian tersebut apabila tidak ditindaklanjuti dengan bijaksana, akan menciderai definisi fungsi bahasa sebagai alat untuk mengekspresikan diri dan untuk menyampaikan pesan.

Ujaran kebencian ini menunjukkan ketidaksantunan berbahasa dalam media sosial sehingga terdapat kecenderungan masyarakat untuk menggunakan bahasa dengan tidak santun yang bermuatan ujaran kebencian. Hal ini merupakan bukti bahwa telah terjadi penurunan nilai-nilai karakter bangsa Indonesia sebagai bangsa Timur yang santun dan berbudaya tinggi. Tentu saja hal ini tidak boleh dibiarkan, karena dapat merusak pembentukan karakter generasi muda harapan bangsa. Untuk itu, hasil penelitian ini diharapkan menjadi dasar para pengajar bahasa Indonesia, baik di tingkat perguruan tinggi maupun sekolah untuk memberikan teladan yang baik kepada peserta didik dalam menggunakan bahasa Indonesia yang baik, benar, da santun pada media sosial. 
Penelitian ini hanya sebatas melihat ujaran kebencian pada kolom komentar YouTube pada tahun politik pemilihan presiden 2019 dengan metode kualitatif. Untuk peneliti lain, bisa menggunakan metode penelitian lain sehingga bisa lebih fokus mengungkap bahasa yang digunakan oleh masyarakat dalam memberikan kritikannya di media sosial YouTube.

\section{Daftar Pustaka}

Al-Ma'ruf \& Imron, A. (2014). Stilistika. Surakarta: Cakra Books.

Anggraeni, D., \& Adrinoviarini, A. (2020). Strategi Pengawasan terhadap Ujaran Kebencian di Media Sosial pada Pemilu. AL WASATH Jurnal IImu Hukum, 1(2), 99-116. doi:10.47776/alwasath.v1i2.60

Asih, D. N., \& Rosit, M. (2018). Opini Publik di Media Sosial: Analisis Isi Opini Kandidat Ahok-Djarot dan Anies-Sandi di Twitter. CoverAge: Journal of Strategic Communication, 8(2), 45-56. doi:10.35814/coverage.v8i2.589

Hasibuan, Z. (2019). Penyebaran Ujaran Kebencian dalam Persfektif Hukum Pidana Islam. ADLIYA: Jurnal Hukum dan Kemanusiaan, 12(2), 183-203. doi:10.15575/adliya.v12i2.4497

Inderasari, E., Achsani, F., \& Lestari, B. (2019). Bahasa Sarkasme Netizen dalam Komentar Akun Instragram "Lambe Turah." Semantik, 8(1), 37. doi:10.22460/semantik.v8i1.p37-49

Juditha, C. (2018). Hoax Communication Interactivity in Social Media and Anticipation (Interaksi Komunikasi Hoax di Media Sosial serta Antisipasinya). Journal $\quad 31$. doi:10.30818/jpkm.2018.2030104

Keraf, G. (2004). Diksi dan Gaya Bahasa. Jakarta: Gramedia.

Kusmiarti, R., Yuniati, I., \& Noermanzah. (2020). Improving Student Communication Skills in Learning Indonesian Language through Collaborative Learning. Retrieved from osf.io/9km3u. International Journal of Scientific and Technology Research, 9(1).

Malau, R. (2013). Efek Media dan Pengadilan Opini. Jurnal The Messenger, 5(1), 31. doi:10.26623/themessenger.v5i1.141 
Masykuri, N. C. (2010). Perkembangan Teknologi Komunikasi dalam Menunjang Fungsi Periklanan dan Public Relation. Humaniora, 1(1), 29. doi:10.21512/humaniora.v1i1.2145

Mawarti, S. (2018). Fenomena Hate Speech Dampak Ujaran Kebencian. Toleransi: Media Ilmiah Komunikasi Umat Beragama, 10(1), 83. doi:10.24014/trs.v10i1.5722.

Medistiara, Y. (2017). Selama 2017 Polri Tangani 3.325 Kasus Ujaran Kebencian. https://news.detik.com/berita/d-3790973/selama-2017-polri-tangani-3325kasus-ujaran-kebencian

Noermanzah, N. (2012). Figurative Language dalam Wacana Drama Seri "Upin dan Ipin" Karya Simon Monjack dengan Tinjauan Deskriptif. Jurnal Perspektif Pendidikan, 5(1), 11-23, https://ojs.stkippgrilubuklinggau.ac.id/index.php/JPP/article/view/347

Noermanzah, N. (2019). Bahasa sebagai Alat Komunikasi, Citra Pikiran, dan Kepribadian. Seminar Nasional Pendidikan Bahasa dan Sastra, Prosiding Seminar Nasional Bulan Bahasa (Semiba), 307, https://ejournal.unib.ac.id/index.php/semiba/article/view/11151/5537

Norhabiba, F., \& Putri, S. A. R. (2018). Hubungan Intensitas Akses Media Baru dan Kualitas Interaksi Lingkungan Sekitar pada Mahasiswa Untag Surabaya. Interaksi: Jurnal IImu Komunikasi, 7(1), 8. doi:10.14710/interaksi.7.1.8-15

Nurel, M. (2018). Majas Sarkasme dalam Penulisan Komajas pada Komentar Warganet dalam Berita "Ahok Banjir Kiriman Karangan Bunga, Fadli Zon: Pencitraan Murahan" (Figure of Speech In Netizen's Comments on the News "Ahok Banjir Kiriman Karangan Bunga, Fadli Zon: Pencitraan Murahan") Mentar pada "Ahok Banjir Kiriman Karangan Bunga, Fadli Zon: Pencitraan Murahan.” Metalingua: Jurnal Penelitian Bahasa, 16(1), 37. doi:10.26499/metalingua.v16i1.150.

Pamuji, E. (2020). Ujaran Kebencian pada Ruang-Ruang Digital. Jurnal Kajian Media, 4(2). doi:10.25139/jkm.v4i2.2811

Riansi, E. S. (2017). Gejala Campur Kode pada Pengunjung Taman Mini Indonesia Indah. Jurnal Membaca (Bahasa dan Sastra Indonesia), 2(2), 175. doi:10.30870/jmbsi.v2i2.2713 
Sudaryanto. (1993). Metode dan Aneka Teknik Analisis Bahasa. Yogyakarta: Duta Wacana University Press.

Takariani, C. S. D. (2015). Opini Nelayan Tentang Akses Informasi Publik. Jurnal Penelitian Komunikasi, 18(2), 101-114. doi:10.20422/jpk.v18i2.40

Undang-Undang Dasar Negara Republik Indonesia 1945, Pasal 28 Ayat 3 tentang Kebebasan Berserikat, Berkumpul, dan Mengeluarkan Pendapat.

Undang-Undang Nomor 11 Tahun 2008 tentang Informasi dan Transaksi Elektronik (UU ITE).

Weeks, B.E. \& Holbert, R.L. (2013). Predicting Dissemination of Newsc Content in Social Media: A Focus on Reception, Friending and Partisanship. Journalism and Mass Communication Quaterly, 90 (2), 12.

Wibowo, Y \& Silaen, S. M. J. (2018). Hubungan Self-Esteem dan Penggunaan Media Sosial Instagram dengan Perilaku Narsisme di Kalangan Siswa Kelas VIII SMPK Penabur Bintaro Jaya. Ikraith-Humaniora, 2(2). 